\title{
WHAT IS THE BEST EDUCATION FOR STUDENTS TO BECOME ENTREPRENEURS? AN ANALYSIS OF DISPARITY IN PSYCHOLOGICAL PROFILES OF STUDENTS BASED ON GRADUATE EMPLOYABILITY ENTREPRENEURSHIP
}

\author{
Anissa Lestari Kadiyono \\ Fakultas Psikologi - Universitas Padjadjaran \\ Indonesia \\ Anissa.lestari@unpad.ac.id
}

\author{
Rezki Ashriyana \\ Fakultas Psikologi - Universitas Padjadjaran \\ Indonesia \\ Rezki.ashriyana@unpad.ac.id
}

\begin{abstract}
Entrepreneur is needed to improve the nation's economy. Students as the next generation and also as productive workforce, will continuing their career as employee or self-employer after graduation. Employability is a key educational concept that has found its way into the Higher Education discourse in the last few years. It's emphasized at how skill-based university training should translate into a smooth transition to work by graduates. This paper presents psychological profile of students based on their graduate employability entrepreneurship. The result shown that there is basic education to improve student's capacity and willingness to have a career as entrepreneurship. The quantitative research has been done on 450 students at West Java, Indonesia using convenience sampling. There are differences at student's psychological profile based on gender, entrepreneurial experiences, social support, and their self-efficacy. Furthermore, a series of employability strategies are presented and analyzed in order to assess their effectiveness. As a conclusion, a number of different initiatives and proposals to improve graduate employability entrepreneurship among psychological resource, activities and entrepreneurship curricula design are presented.
\end{abstract}

Keywords - Graduate Employability Entrepreneurship, Entrepreneurship Educational Program, Psychological Profiles, Students

\section{INTRODUCTION}

One of the basic employment problems facing Indonesia is the problem of unemployment. From year to year unemployment in Indonesia is increasing, especially college graduates. According to BPS (2016) data, the open unemployment rate for university graduates or undergraduate (S1) actually increased significantly. The data of 2016 unemployment of 695,304 people increased from previous years, unemployment rate of university graduates increased from 5.34 percent to 6.22 percent.

The number of unemployment may be due to low competence and lack of soft skills owned by the prospective workforce so that the allocation of employment is not fully met. It is also still attached mentality to find a job rather than create their own work. Many job positions in Indonesia are filled by unqualified workers. Specifically, data obtained by the Ministry of Manpower Ministry's Employment Service Center shows that open unemployment in Indonesia is partly due to skill incompatibility between registered job seekers and registered vacancies (ILO Key Labor Market Indicators, 2014). Efforts to anticipate the increasing number of unemployed are done by identifying the worker figure required by graduate users. Many studies show that graduate users need workers who have the ability to adapt to new circumstances in the century.

In Indonesia, the most open unemployment data in 2016 is Banten Province, followed by West Java and Jakarta. West Java occupies the second position that has the highest unemployment in Indonesia and the capital of West Java Province is located in the city of Bandung. So in this study the researchers highlight the city of Bandung, besides Bandung is the largest metropolitan city in West Java. The city is located 140 $\mathrm{km}$ southeast of Jakarta, and is the largest city in the southern part of Java Island. While the area of Bandung Raya (Metropolitan Region of Bandung) is the second largest metropolitan in Indonesia after Jabodetabek. In addition, according to BPS (2015), the city of Bandung is the second most populous city in West Java, this is causing more and more job vacancies 
that must be available. According to data from the Manpower Office Bandung noted until the end of 2015 , the number of unemployed in Bandung continues to increase about 107,565 people who do not have a job. The number of unemployed is increasingly increasing, proven unemployment in the city of Bandung in 2016 has reached 117,532 inhabitants. This figure is equivalent to 9.02 percent of the total labor force of 1.19 million.

Based on these problems, Entrepreneurship is needed to develop the nation's economy and improve the nation's competitiveness. This study was conducted to determine whether entrepreneurship is a student's career choice. This paper has purpose to present attitude theory as an alternative to the trait and demographic approaches used to study entrepreneurs as graduate employability. The major role in working up attitudes towards life, raising enterprising people is played by educational system, which should be developing and propagating entrepreneurial initiative among graduate students at higher eduation at West Java, Indonesia.

\section{LITERATURE REVIEW}

To gain a competitive edge in the job market, graduates must develop work abilities while in their college. In research (Qenani, MacDougall, Sexton, 2014) colleges / universities have an increasingly important role in developing and improving graduate employability for working at company. Job readiness is a transition from college to work or referring to Employability. With employability, it can help fresh graduate college graduates to shorten their learning curve in transition into the working world because undergraduate degrees are insufficient to ensure a rewarding future career. Employability is a form of specification of active adaptation in work that allows employees to identify and realize career opportunities (Fugate, Kinicki \& Ashforth, 2004).

According to Rothwell and Arnold (2007), where employability is defined as the ability of individuals to keep working or looking for other work in accordance with their interests and desires. While employability skills are a skill that allows one to get a job or to be able to keep working, including personal skills, interpersonal skills, attitudes, habits, and behavior (Lankard, 1990). Employability is a concept set up to help individuals adapt actively in the work world so as to help individuals to identify and understand opportunities in work. Thus, employability can facilitate the movement between jobs, both within and outside the organization, this is because employability increases the likelihood of a person getting a job.

The employability concept by Fugate, Kinicki, and Ashforth (2004) emphasizes an active proactive and adaptation approach so that employability can assist individuals in identifying career opportunities and facilitating the movement between jobs. This theory is becoming more relevant to researchers to fresh graduates because the theory of Fugate, Kinicki, and Ashforth (2004) can be used in various career contexts such as job search and job retention (McArdle et al., 2007).

There are four ways of enhancing student employability are: Work Experience Employers generally prefer to hire people who have workplace experience, especially those who can show what they have learned from it, so one way of increasing students' competitiveness in the labour market is to design work attachments into degree programmes. Entrepreneurship Modules Although there is a lot of interest in adding entrepreneurship to the curriculum, this strategy is open to much the same objection as work attachments. Good enrichment strategies have most impact when the underlying curriculum stimulates those complex learning achievements that underlie entrepreneurship. Portfolios, Profiles and Records of Achievement Portfolios (sometimes called profiles, sometimes records of achievement) should get students reflecting on their achievements; collecting and presenting supportive evidence; identifying and then acting on priorities for development.

\section{RESEARCH METHOD}

This research approach is non-experimental research approach. The method used is descriptive and verificative research method. According to Sugiyono (2013), the descriptive method is a method that is used to describe or analyze research results but is not used to make broader conclusions. To determine the sample that will be used in the study, researchers used a nonprobability sampling. The population of this research is higher education graduates form West Java, Indonesia. Sampling techniques used is convenience sampling.

\section{Participants}

The participants consisted of 450 people $(67.5 \%$ female and $32.8 \%$ male) from Privat \& State University in West Java-Indonesia. They ranged in age from 20 years to 27 years with a mean age was 24,20 years $(\mathrm{SD}=1.27)$. Their educational background, mostly in sosiohumaniora $(53,52 \%)$.

\section{Measures}

Graduate Employability. Graduate Employability was assessed using questionnaire constructed by Fugate (2003). Responses to each item were made on a 5 -point Likert scale (1- strongly disagre to 5 - strongly agree). Scores for each of the dimensions, were calculated as the average of the responses to each the items corresponding to the dimension. For summary purposes, an overall graduate employability score was also computed as the average of the dimension scores. 
This score in essence represents a unit weighted composite of the subscale scores.

\section{RESULT \& DISCUSSION}

In general, Graduate employability of college graduates is at a fairly high level. The description of employability can be explained in the framework of research as following picture:

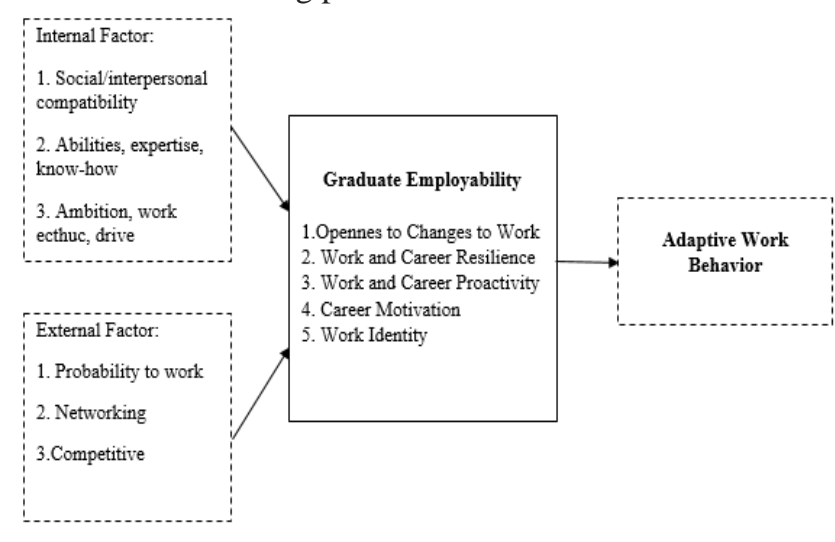

Figure 1. Research Framework

Fresh graduate employees will have a difficult, disappointing, and stressful time in their first year of work. Individuals need adaptation skills in the face of a transition to entering a stressful world in their first year of work. Therefore individuals need adaptation skills in the face of the transition into a stressful world of work, so they need to improve themselves in entering the workforce.

The employability concept according to Fugate, Kinicki, and Ashforth (2004) emphasizes an active proactive and adaptation approach so that employability can assist individuals in identifying career opportunities and facilitating the movement between jobs. This theory is becoming more relevant to researchers to fresh graduates because the theory of Fugate, Kinicki, and Ashforth (2004) can be used in various career contexts such as job search and job retention (McArdle et al., 2007).

Viewed from the demographic side of employees, the respondents' gender composition is as follows:

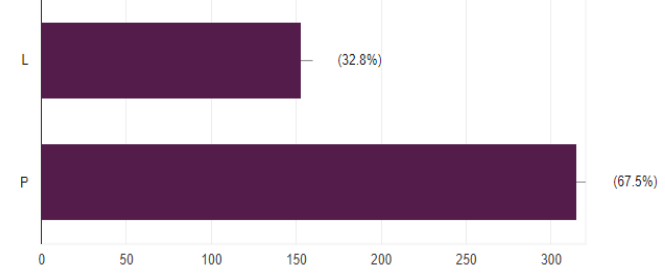

Figure 2. Demographic of Respondents
Major of respondents educational background is came from sosiohumaniora, such as Psychology, Literature, Social Welfare, Politic, Communication Studies, and others. Based on their experience during their entrepreneurial activities, the profile of respondents is as follows:

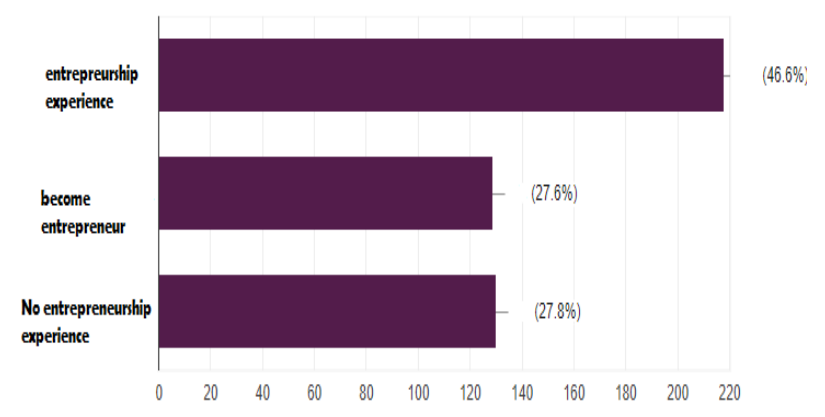

Figure 3. Entrepreneurship Activities of Respondents

This shows that $76 \%$ of respondents have been or are entrepreneurs. Only about 27\% never undertake entrepreneurial activities. It's mean, major of responden has positive attitude toward entrepreneurship.

Employability is a form of specification of active adaptation in work that enables prospective employees to identify and realize career opportunities (Fugate, Kinicki \& Ashforth, 2004). According to Rothwell and Arnold (2007), where employability is defined as the ability of individuals to keep working or looking for other work in accordance with their interests and desires. While employability skills are a skill that allows one to get a job or to be able to keep working, including personal skills, interpersonal skills, attitudes, habits, and behavior (Lankard, 1990). Employability is a concept set up to help individuals adapt actively in the work world so as to help individuals to identify and understand opportunities in work. Thus, employability can facilitate the movement between jobs, both within and outside the organization, this is because employability increases the likelihood of a person getting a job.

In conducting entrepreneurial activities, it turns out that collaboration is a motivator for respondents to realize entrepreneurship. Collaboration among friends, resellers, franchises, and others are forms of collaboration that indicate that the adaptation form of college graduates to be able to realize a career in the field of entrepreneur is to share the risk through the way of collaboration compared with self-effort. The average respondent has a moderate self-esteem, so it requires strengthening to improve entrepreneurial behavior that initially just try and join friends into the form of independent business as the embodiment of future career development. The chart on this can be seen in the chart as follows: 


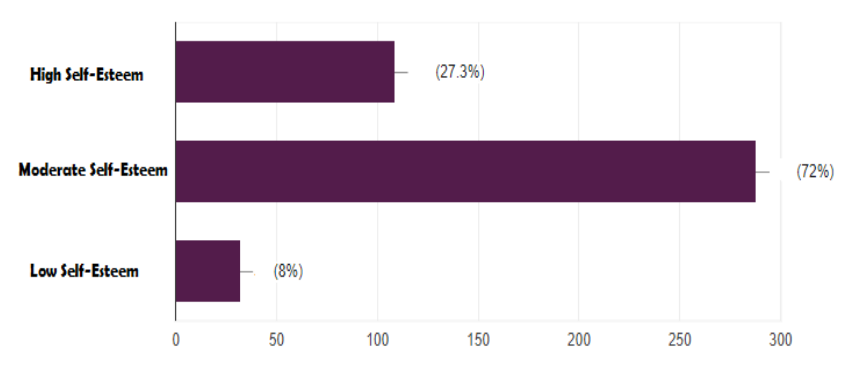

Figure 4. Entrepreneurial Activities

Therefore, universities that produce graduates and prospective workers need a basic pattern of graduates development, such as training in the field of work, development of scientific knowledge in the field of work, the preparation of portfolio of graduates, providing opportunities for students to experience work experience that can encourage them to Increasing the mastery of the task field, current knowledge, as well as the improvement of skills needed to improve graduate employability of college graduates become more competitive and ready to work.

\section{CONCLUSION}

- In general, graduate level employability owned by college graduates in West Java is at level 7 from 10 scale or quite high Graduate Employability

- Most of them have an interest in entrepreneurship

- Things that need to be improved in entrepreneurship attitude are self-esteem of graduates in order to have confidence in themselves and ability in facing challenge after graduation

- Needs for improvement in college is the presence of training to improve the skills possessed, student's Work experience, and develop the latest knowledge about developments in the industry they will be working on.

- The role of universities is very high in the effort to prepare graduates to be absorbed by the market and employment industry.

\section{REFERENCES}

[1] The Central Bureau of Statistics Indonesia. website. [Online]. Available: https://www.bps.go.id

[2] http://belmawa.ristekdikti.go.id/dev/wpcontent/uploads/2015/11/6A-PanduanPenyusunan-CP.pdf

[3] http://www.kopertis12.or.id/wpcontent/uplods/2016/04/3.-Pnduan-KPT-2016endro.compressed.pdf
[4] http://www.ilo.org/wcmsp5/groups/public/--asia/---ro-bangkok/---ilojakarta/documents/publication/wcms 381565.pdf

[5] https://m.tempo.co/read/news/2016/05/04/173768 481/bps-pengangguran-terbuka-di-indonesiacapai-7-02-juta-orang

[6] Fugate M, Kinicki AJ, Ashforth BE (2004) Employability: A psycho-social construct, its dimensions, and applications. Journal of Vocational Behavior 65(1): 14-38. Google Scholar

[7] Gorman, G., Hanlon, D., King. W. Some research perspectives on entrepreneurship education and education for small business management : a tenyear literature review. International Small Business journal. (1997). Vol. 15 (3), 56-77

[8] Kuratko, D.F. The emergence of entrepreneurship education : Development, challenges, and trends. Enterpreneurship Theory and Practice. (2005). Vol. 29 (1). 577-597.

[9] Lankard, B. A. Employability--the fifth basic skill. ERIC Digest No. 104. Columbus: Center on Education and Training for Employment. The Ohio State University. (ED 325 659) (1990).

[10] McArdle, S., Waters, L., Briscoe, J., \& Hall, D. Employability during Unemployment: Adaptability, career identity and human and social capital. Journal of Vocational Behavior, 71, 247-264 (2007)

[11] Peterman, N.E., \& Kennedy, J. Enterprise Education : Influencing student's perceptions of enterpreneurship. Entrepreneurship Theory and Practice, Winter. (2003). 129-144

[12] Qenani, MacDougall, Sexton. An Empirical Study of Self-Perceived Employability: Improving the Prospects for Students Employment Success in an Uncertain Environment. Active Learning in Higher Education Journal (2014

[13] Rothwell A, Arnold J (2007) Self-perceived employability: Development and validation of a scale. Personnel Review 36(1): 23-41. Google $\underline{\text { Scholar }}$

[14] Sugiyono. Metode Penelitian Kuantitatif, Kualitatif, dan R\&D. Bandung : Alfabeta (20013) 